\title{
$\mathrm{BF}_{3}$ 測定における付加的メモリ一効果
}

\section{An Additional Memory Effect in Mass Spectrometry for $\mathrm{BF}_{3}$}

\author{
星野紀一*, 里 岡 栄* \\ Kiichi Hoshino, Sakae Satooka
}

（1978年1月11日受理）

\begin{abstract}
It is considered that the memory effect appears in a metallic gas inlet of a mass spectrometer for measurement with samples of $\mathrm{BF}_{3}$ is classified into two kinds, one is essential memory effect which is caused by an action between the surface of metal and $\mathrm{BF}_{3}$, and the other is additional memory effect which is caused by viscous liquid produced by reaction among water, $\mathrm{BF}_{3}$ and metals. The additional memory ef fect is caused by stain on the inner surface of the gas inlet. Air is introduced into the sample bottle joint at each time for change of sample bottle. Moisture in the air is adsorbed on inner surfaces of the joint and piping made of metal, and combined with $\mathrm{BF}_{3}$ which is introduced, and then viscous compound is produced by dissolution of the metal into the compound made from $\mathrm{H}_{2} \mathrm{O}$ and $\mathrm{BF}_{3}$. The vapour pressure of the viscous compound is not sufficient low, and so the compound propagates from the sample bottle joint to the whole of the gas inlet at each time of opening and closing of valves of the gas inlet. The coated film of the viscous compound with adsorption and release of $\mathrm{BF}_{3}$ is a cause of the additional memory effect. If the stain of the inner surface of the gas inlet grows up, the additional memory effect becomes more intense compared with the essential memory effect, and the measured values are not converged. To remove the additional memory effect, it is desirable to introduce the sample $\mathrm{BF}_{3}$ after the moisture intruded into the piping by the exchange of sample bottles is removed sufficiently by introduction of $\mathrm{F}_{2}$ or $\mathrm{ClF}_{3}$.
\end{abstract}

\section{1. 緒言}

試料に $\mathrm{BF}_{3}$ を用い， ${ }^{10} \mathrm{~B}$ の存在比を測定する質舅分 析法で問題になるのは,メモリー効果である。このメ モリー効果は, ガスインレットとイオン源内部で起こ るが，その大きな発生源はガスインレットである。ガ スインレットはフッ化物のガスを扱うので, ガラス製
のものは長い間に侵される。ニッケルやモネルメタル を忉料として作ったもののほうが良いが，これらの金 属製のものでは, ガスの吸着が多く,メモリー効果が 大きく現われる。

イオン源はメモリー効果を考虑して設計してある

が, メモリー効果が全然現われないようにすることは できない。しかし，試料ガスを流すことにより，ガス

*理化学研究所同位元素研究室 (埼玉県和光市広沢 2-1)

The Institute of Physical and Chemical Research (Hirosawa 2-1, Wako-shi, Saitama, Japan). 
に接する面の吸着層は試料カスに洗われ，新しい試料 に罾き替えられるので，長期間试料を流がすことによ り，メモリ一効果を消すことは比較的容易のように思 われる。一方，金属製のガスインレットによるメモリ 一効果は，容易に解決できない。

$\mathrm{UF}_{6}$ 用の質量分析計では, 測定範囲が割合狭かっ たので,メモリ一効果はあまり問題にならなかった が, $\mathrm{BF}_{3}$ 測定用啠量分析計では測定範囲が広いので, メモリ一効果が大きく現われる。 ${ }^{10} \mathrm{~B}$ の天然同位体存 在比は $20 \%$ 程度であり，簡単な濃縮装置で容易に 100 \%近くまで濃縮される。 $\mathrm{BF}_{3}$ 試料を測定するときは， 濃度が著しく変化するので, メモリー効果が測定に大 きな影響を与える。 $\mathrm{BF}_{3}$ 用の質量分析計を設計すると きは, $\mathrm{UF}_{6}$ 測定用のものにくらべ，メモリー効果を簡 単に考えがちであるが，実は前者のほうがこの効果に 関する限り厄介であることがわかった。メモリー効果 は,ガスインレット，イオン源，排気系の注意深い設 計および測定時の操作により大きく改善される。

ここで用いた質量分析計は, 1975 年 6 月から稼動 し，1977年 2 月まで実験して得られた結果をここに述 ベる。

\section{2. 付加的メモリーの起因}

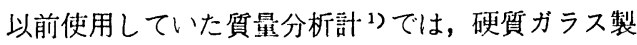
のガスインレットを用いて抢り，それによるメモリー 効果は小さかった。しかし，ガラス製ガスインレット 用のバルブには良いものがなく，取扱上不便であっ た。 $\mathrm{BF}_{3}$ 用のリザーバーに硬質ガラスを使用すること の良否については，まだ結論がでない。

ガスインレットを金属製にすると，メモリー効果は 藷しい。これは以下に述べる諸点が主な原因であると 思われる。試料ビン取りつけジョイントおよび配管の 一部には，武料取り替えのたびに空気が入る。それを 繰り返しているうちに，内部に暗緑色の粘度の高い液 体が付着する。その量は取り替えた回数に比例して増 大する。この粘液ができると, 排気の際真空度がなか なか上がらない。これは，この物質の蒸気圧が低くな いことを意味している。試料ビンジョイント部から， ガスリザーバーに試料を送り込む操作を繰り返すうち に，配管やリザーバーに粘液状の物質が少しづつ送り 込まれて, 器壁に被膜を作る。ガラス製のガスインレ ットの場合には，このような付着物はできなかった。
この付着物の発生は次のように考えるべきである。 试料ビンを取り替えるたびに，ジョイントから空気 が入り, 空気中の水分が金属面に吸着され，次に導入 される $\mathrm{BF}_{3}$ と反応する。水 $-\mathrm{BF}_{3}$ 系の反応については, 多くの研究がなされている。3)・6) C. A. Wamser ${ }^{3)}$ によ机ば, $\mathrm{BF}_{3} ・ \mathrm{H}_{2} \mathrm{O}$ や $\mathrm{BF}_{3} \cdot 2 \mathrm{H}_{2} \mathrm{O}$ は，水に $\mathrm{BF}_{3}$ の ガスを吸収させて作られる。水に $\mathrm{BF}_{3}$ が吸収される場 合，初めは吸収されにくいが，しばらくすると吸収さ れるようになる。通常，水と $\mathrm{BF}_{3}$ のモル比が $8: 1$ 位. から, $\mathrm{B}(\mathrm{OH})_{3}$ が析出しはじめ, $\mathrm{BF}_{3}$ を增して水と $\mathrm{BF}_{3}$

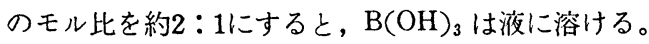
さらに $\mathrm{BF}_{3}$ を增してモル比を完全に $1 ： 1$ にするには 長時間を要するが, $1: 0.9$ 位までは比較的短時間に 進行する。水一 $\mathrm{BF}_{3}$ 系では, 温度によって $\mathrm{BF}_{3}$ が遊離 したり，吸収されたりする。水一 $\mathrm{BF}_{3}$ の反応方程式は， 反応速度論的考察から以下のように表わされる。3)4

1) $\mathrm{BF}_{3}+\mathrm{H}_{2} \mathrm{O} \rightleftarrows \mathrm{HBF}_{3}(\mathrm{OH})$ [非常に早い]

2) $\mathrm{HBF}_{3} \mathrm{OH}+\mathrm{H}_{2} \mathrm{O} \rightleftarrows \mathrm{HBF}_{2}(\mathrm{OH})_{2}+\mathrm{HF}$ [早小]

3) $\mathrm{HBF}_{2}(\mathrm{OH})_{2}+\mathrm{H}_{2} \mathrm{O} \rightleftarrows \mathrm{HBF}(\mathrm{OH})_{3}+\mathrm{HF}[$ 早い]

4.) $\mathrm{HBF}(\mathrm{OH})_{3} \rightleftarrows \mathrm{B}(\mathrm{OH})_{3}+\mathrm{HF}$

[早い]

5) $\mathrm{HBF}_{3} \mathrm{OH}+\mathrm{HF} \rightleftarrows \mathrm{HBF}_{4}+\mathrm{H}_{2} \mathrm{O}$

[䢰い!

平衡時には, $\mathrm{HBF}_{4}, \mathrm{HBF}_{3} \mathrm{OH}, \mathrm{HBF}_{2}(\mathrm{OH})_{2}, \mathrm{HBF}$ $(\mathrm{OH})_{3}$ および $\mathrm{B}(\mathrm{OH})_{3}$ などが存仼する。 $\mathrm{HBF}_{4}$ や $\mathrm{HBF}_{3} \mathrm{OH} /$ は金属や金属酸化物を溶かすと報告されてい る。

ガスインレット内にできた暗緑色の粘性物質は，水 と $\mathrm{BF}_{3}$ と金属の化合物であると思われる。この化合物 が存在すると， $\mathrm{BF}_{3}$ がこの中に吸収され，化合物中の $\mathrm{BF}_{3}$ が交換放出されたりして，メモリー効果の原因に なるものと思われる。

粘性の付着物によるメモリ一効果は，技術的に除き うるものであるが，本貿的なメモリ一効果が存在す る。この本質的なメモリ一効果は，器壁の荒さによる と云う説があり 1 ，また金属器壁の酸化物に $\mathrm{BF}_{3}$ が作 用して付加化合物が出来ることが原因であると云う説 もある ${ }^{8)} 。 \mathrm{BF}_{3}$ が金属に吸着されることのみが原因で あるとすると，このメモリ一効果は大きすぎるので， 金属面に何かしっかりした層ができることが原因とみ るほうが, 妥当である。 


\section{3. 装置の構成}

\section{1. 分 析管}

$60^{\circ}$ 偏向単収束型。材質は。SUS 27 。イオン源室と

分析部を差動排気する方法を採用した。
軌道半径
$15 \mathrm{~cm}$
イオン加速電圧
$1.5,2,2.5,3 \mathrm{kv}$
コレクター
シングルコレクター
イオン電流增巾器 振動容量型電位計
記録計
自動切換倍率器付きペンレコ

イオン源 電子衝撃型 衝撃電子流 $70 \sim 300 \mu \mathrm{A}$

排気系分析管を差動排気型にして, イオン源

室, 分析部各々 $20 \ell / \sec$ のーブルイ

オンポンプ**を使用。荒引用にソープ

ションポンプ**を使用した。

ガスインレットの排気には, $100 \mathrm{l} / \mathrm{m}$

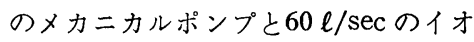
ンポンプ**を使用。その他に, $F_{2}$ 排気

用としてケミカルポンプを使用した。

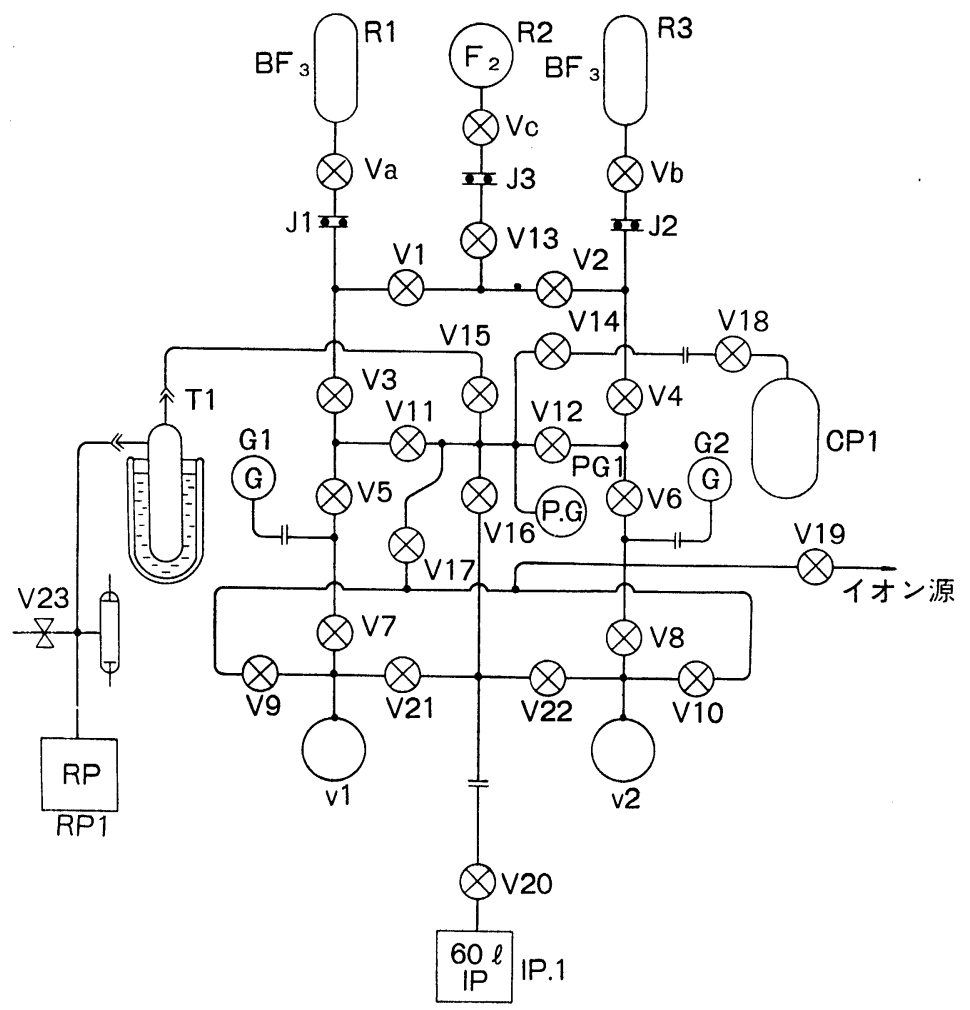

Fig. 1. Schematic diagram of a gas inlet for $\mathrm{BF}_{3}$ used in our works.

V3, 4......16, 17

V1, 2, 3, 19, Va, Vb \& Vc

V $18,20,21 \& 22$

G1, 2

RP 1

IP 1

CP 1

PG 1

T 1

R 2
HOKE diaphragm sealed valves, monel, cam handle, 1/4"

HOKE bellows sealed valves, monel, $0.156^{\prime \prime}$ orifice

NUPRO bellows valves $8 \mathrm{BK}$, stainless

Bellows manometers, stainless²)

Mechanical pump $100 \ell / \mathrm{min}$.

- Ion pump $60 \ell / \mathrm{sec}$

Chemical pump

Pirani gage with Pt filament

Glass cold trap

$\mathrm{F}_{2}$ gas reservoir

\footnotetext{
**日電バリアン製
} 


\section{2. ガスインレット}

ガスインレットの構成を Fig. 1 に示す。これは 2 系 統からなり， 2 種類の試料ガスを貯えることができ る。このガスインレットは，第 2 章で述べたことを考 虑してある。

V 18，20，21および22を除くバルブの配管は全部銀 蠟 $\left(604{ }^{\circ} \mathrm{C}\right.$ イージーフロー) で接続した。ジョイン ト J1, J2 はウラン測定用の質量分析計の北料ビンジ ョイント2)の改良型を用いた。シールはバイトン製 $\mathrm{O}$ リングを用いた。

カススイレットは，配管やバルプにリボンヒーター を捲き通電することにより, $200^{\circ} \mathrm{C}$ まで加熱できる。

$\mathrm{CP1}$ は，カスインレット中に導入された $\mathrm{F}_{2}$ ガスを排 除するためのケミカルポンプである。ガスインレット の中では， $\mathrm{F}_{2}$ で清浄にする操作で HF が発生する。 $\mathrm{F}_{2}$ や $\mathrm{HF}$ ガスを排気するため, $\mathrm{NaOH}$ を詰めたケミカル トラップを通して，迴転ポンプで排気すると良いよう に思われるが，この方法ではごく少量であるが $\mathrm{F}_{2} や$ $\mathrm{HF}$ が空気中に放出され，健康上好ましくない。この 理由で, Fig. 2 に示す構造のケミカルポンプを試作し,

(3)

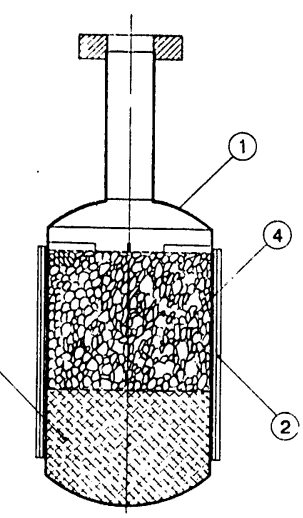

Fig. 2. Cross section of chemical pump

1. Container

2. Electric heater

3. Molecular sheaves

4. $\mathrm{Mg}$ pellets

$\mathrm{F}_{2}$ ， $\mathrm{HF}$ 等のガスを完全に補えることに成功した。こ れを動作させるには, まず容器 1 を排気し, 排気しな がら 2 に通電して 1 を加熱する。そのとき 3 および 4 から大量の空気が放出される。容器 1 の真空度が良く
なってから，排気を止め加熱を停止する。 $F_{2}$ カススは $\mathrm{Mg}$ と化合して捕えられる。 $\mathrm{Mg}$ の細片の表面は， $\mathrm{O}_{2}$ と化合しているので, $\mathrm{F}_{2}$ の量に比例して $\mathrm{O}_{2}$ を放出す る。この $\mathrm{O}_{2}$ は 4 の層に吸着される。排出されるガス に $\mathrm{F}_{2}$ 以外のガスが含ま机ていても，ケミカルポンプは 正常に動作する。これを長時間使用したあと，2に通 電して加熱することにより，それからカスが放出され る。もし 4 の㿉に $\mathrm{F}_{2}$ が吸着されていても，放出され ると 3 に捕えられるので，ケミカルポンプを加熱した とき， $\mathrm{F}_{2}$ が排出される可能性はない。このポンプの動 作だけでは，真空度はガイスラー管が消える程度まで しか良くならない。真空度を上げるためにはイオンポ ンプで排気する。

Fig. 1 に示すガスインレットは試料ガス压を20３0 Torrで使用しリリークを通してイオン源に接続する。

\section{3. イオン源}

$\mathrm{BF}_{3}$ 測定用のイオン源は， $\mathrm{UF}_{6}$ 用のものに比へ， 電極の污れは少ない。したがって，普通使われている 電子衝繋型のイオン源でも使用可能である。电子流が イオン化函のスリットの周辺に当ることは，沅れを增 し性能を損なうので，电子流の貫通率の良いーアピン 型フィラメント2)を採用した。そのため, 電子流のほ ぼ100\%がエレクトロントラップに到達する。

メモリー効果については，电極におけるものを小さ くするために，イオン化氯は開放型にした。イオン化 阘とイオン引出し电極との間に $1.5 \mathrm{~mm}$ ほどの間䏚を 設け，中のガスを排父しやすい構造にした。このため に，イオン化效率が低くなることを少しでも防ぐため に，イオン化函に入る試料カススは，板状の噴流にして 供給する構造をとった。この噴流の入口は, イオン化 函のイオン射出スリットの反対側に設けた。

貫通電子流を $200 \mu \mathrm{A}$ 程度流すことにより，充分強い イオン電流が得られた。

配管におけるメモリー効果を小さくするためには， 内部の試料ガスの压力を充分宫くして使うことが肝要 である。試料ガスはイオン化函の近くで減圧すれば, 理想的であるが, 修理とか流量調整のことを考えると リークをイオン源のフランジに設けのが良いように思 われる。Fig. 3は, イオン源フランジに設けたリーク を示す。リークからイオン化函までの距離は約 $12 \mathrm{~cm}$ である。内径は $3 \sim 4 \mathrm{~mm}$ である。取り扱いやすい構 造にするために,この程度の空容積が必要となる。 


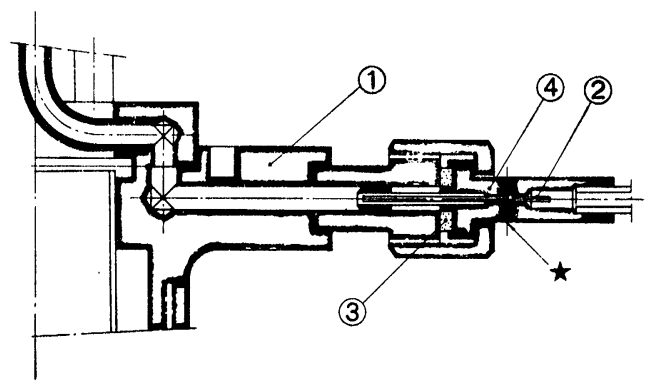

Fig. 3. Leak for reducing of gas pressure built in a flange of an ion source.

1. Ion source flange (stainless)

2. stainless capillary, id $0.20 \phi$, od $0.42 \phi$, $3 \mathrm{~cm}$ in length. Gas flow is adjusted by deformation of cross section of the capillary.

3. Teflon gasket

4. Joint

$\star$ The capillary is silver soldered in this hole.

\section{4. 実験}

\section{1. 試料ビンジョイント部の污れ}

ガスインレットにつけてある試料ビンを外し，再び ビンを取りつけた後, 排気し, 㨁ちに $\mathrm{BF}_{3}$ を導入する という操作を繰り返すと, ショョイント内部に暗緑色の 粘性の付着物ができる。

試料を取り替えるとき，ジョイント部の空気の排気 後， $\mathrm{F}_{2}$ ガスを導入し温度を $200^{\circ} \mathrm{C}$ に上げて脱水する と，暗緑色の付着物は生じなかった。またジョイント 部の内部に生じた暗緑色の付着物は，元こを排気後 $\mathrm{F}_{2}$ カスを導入し，加熱すると分解して粉来状になった。 この粉末状の層は, ガスをジョイント部に封入し, 充 分加熱して排気する操作を何回も繰り返しても除去す ることができなかった。このように器壁上に残った粉 㶬状の蟹は, 機械的に取り除く以外に良い力法がな い。

ガスインレット内を清浔にする能力は, $\mathrm{ClF}_{3}$ は $\mathrm{F}_{2}$ より少し少るが，大体同じようである。
ジョイント内に粘性の化合物が出来ると，排気した とき真空度がなかなか上がらないので，この粘性の化 合物が出来る様子を調へた。

Fig. 4に示すような，パイレックスガラス製の容器

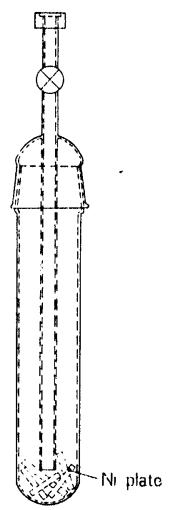

Fig. 4. Vessel for experiment on the reaction of $\mathrm{H}_{2} \mathrm{O}$ and $\mathrm{BF}_{3}$.

に短冊形のニッケル板を封入した。カラス製容器は発 生するフッ化物に侵されるので好ましくないが, 中が 見えるので，予備的実験には都合がよい。次の順序で 実験を繰り返した。

(1) 排気 $\left(10^{-3}\right.$ Torr $)$,

(2) $\mathrm{BF}_{3}$ ガス封入 (760 Torr 1 昼夜放置)

(3) 排気 $\left(10^{-3}\right.$ Torr $)$,

(4) 大気封入 (3 分間)

操作 5 回目ごろから，ニッケル板の表面に青白色の 粉が付着しはじめ, 同時に液状のものも付着した。12 回目ごろ路状の青緑色の液体がニッケル板表面に付着 した。操作を繰返すと液体の量は徐々に增加し，小さ な結晶が液の中に生成した。この状態がしばらく続い たあと, 30回目頃になって, 长の結晶が溶けて青緑色 の粘液になった。この粘液は大気中に取り出すと白煙 を生じた。

この実験で得られた粘液を質量分析計***で分析し た結果を Fig. 5 に示す。 $\mathrm{OH}^{+}, \mathrm{H}_{2} \mathrm{O}^{+}, \mathrm{F}^{+}, \mathrm{HF}^{+}, \mathrm{O}_{2}{ }^{+}$, $\mathrm{BFOH}^{+}, \mathrm{BF}_{2}{ }^{+}, \mathrm{BF}_{3}{ }^{+}, \mathrm{HBF}(\mathrm{OH})_{3}{ }^{+}, \mathrm{HBF}_{2}(\mathrm{OH})_{2}{ }^{+}$, $\mathrm{BF}_{3} \cdot \mathrm{H}_{2} \mathrm{O}^{+}$および $\mathrm{HBF}_{4}+$ などのピークが現われている。

***.日立製作所製RMU-6MG 


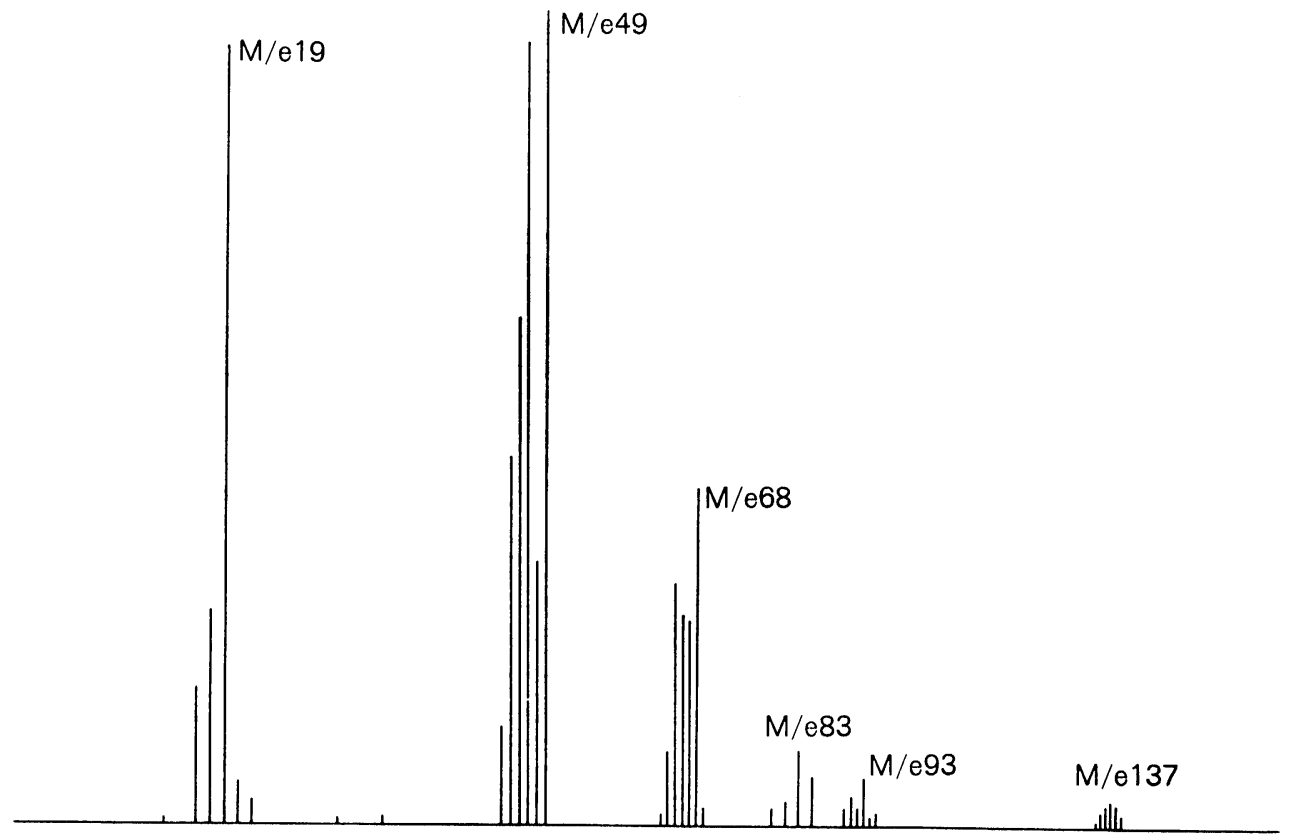

Fig. 5. Diagram of mass spectra of viscous compond produced in piping of a metallic gas inlet.

測定方法が不適当なのか，金属のイオンは検出されな かった。

ニッケル板の代りにステンレスの網を用いて同様の 実験を行ない, 得られた粘液を化学的に定性分析し た。鉄が最も多く，クロム，ニッケルなどステンレス の成分が検出された。

\section{2. ガスインレット内の清浄と放出ガス}

カスインレッとおよび 分析管を加熱 $\left(200 \sim 250^{\circ} \mathrm{C}\right)$ したときに出るガスおよびそのあと， $\mathrm{F}_{2}$ ガスと $\mathrm{NH}_{3}$ ガスを導入して加熱したときに出るカススについて検討 した。質量分析計の走查を繰返し，記録されたマスス ペクトルから読み取った止なイオンのイオン強度の時 間的変化を，Fig. 6,7 拈よび 8 に示す。四には一走 监で得られた質量スペクトルのイオン強度を, 同じ時 刻の值に修让してホしてある。一走查の質量範囲は, $M / e$ 17 55 で, 走查時間は約 7 分半である。幾つか の実験を比較するには, 実験前の装置の污れの度合が 同じでなければならない。Fig. 6, 7 拉よび8に示す 実験の前に, 濃縮実験で得られた $\mathrm{BF}_{3}$ 試料を 20 検体
測定して，実験前の状態をそろえた。この後の実験で は, 導入の際にショョイント部は前もって $\mathrm{F}_{2}$ で脱水処理 を行なった。

ガスインレットを室温 $\left(23 \sim 25^{\circ} \mathrm{C}\right)$ から加熱したと き放出されるガスについて，イオン強度の時間変化を Fig. 6(A) に示す。また，分析管とガスインレットの 間のバルブを閉じ，分析管を加熱したときに放出され るガスによるイオンの強度変化を，Fig. 6(B)に示す。 イオンの種類は. $(\mathrm{A})$ と(B)では, $M / e$ 36を除き同じ である。 $M / e$ 36は分析管側にだけ現われる。(A), (B) 阔方に, $M / e 18\left(\mathrm{H}_{2} \mathrm{O}^{+}\right), 20\left(\mathrm{HF}^{+}\right), 28\left(\mathrm{~N}_{2}\right), 32\left(\mathrm{O}_{2}{ }^{+}\right)$, $44\left(\mathrm{CO}_{2}{ }^{+}\right), 47\left({ }^{11} \mathrm{BFOH}^{+}\right), 48\left({ }^{10} \mathrm{BF}_{2}{ }^{+}\right), 49\left({ }^{11} \mathrm{BF}_{2}{ }^{+}\right)$な どのイオンが現われた。なお， $M / e 36$ のイオンは， 以前に $\mathrm{ClF}_{3}$ を用いて洗條の効果を試験したことがあ ったので, $\mathrm{H}^{35} \mathrm{Cl}^{+}$によるものと思われる。

室温でカスインレットにF $\mathrm{F}_{2}$ ガス (40 Torr) を導入 し, $M / e 38$ を除く他のイオンの強度がほぼ安定して から加熱し，放出されたカスを分析した結果を Fig. 7 （左図）に示す。ガスインレットを加熱せずに $\mathrm{F}_{2}$ を導 入したとき, $M / e 38$ のイオン電流は $1 \times 10^{-10} \mathrm{~A}$ 位ま 


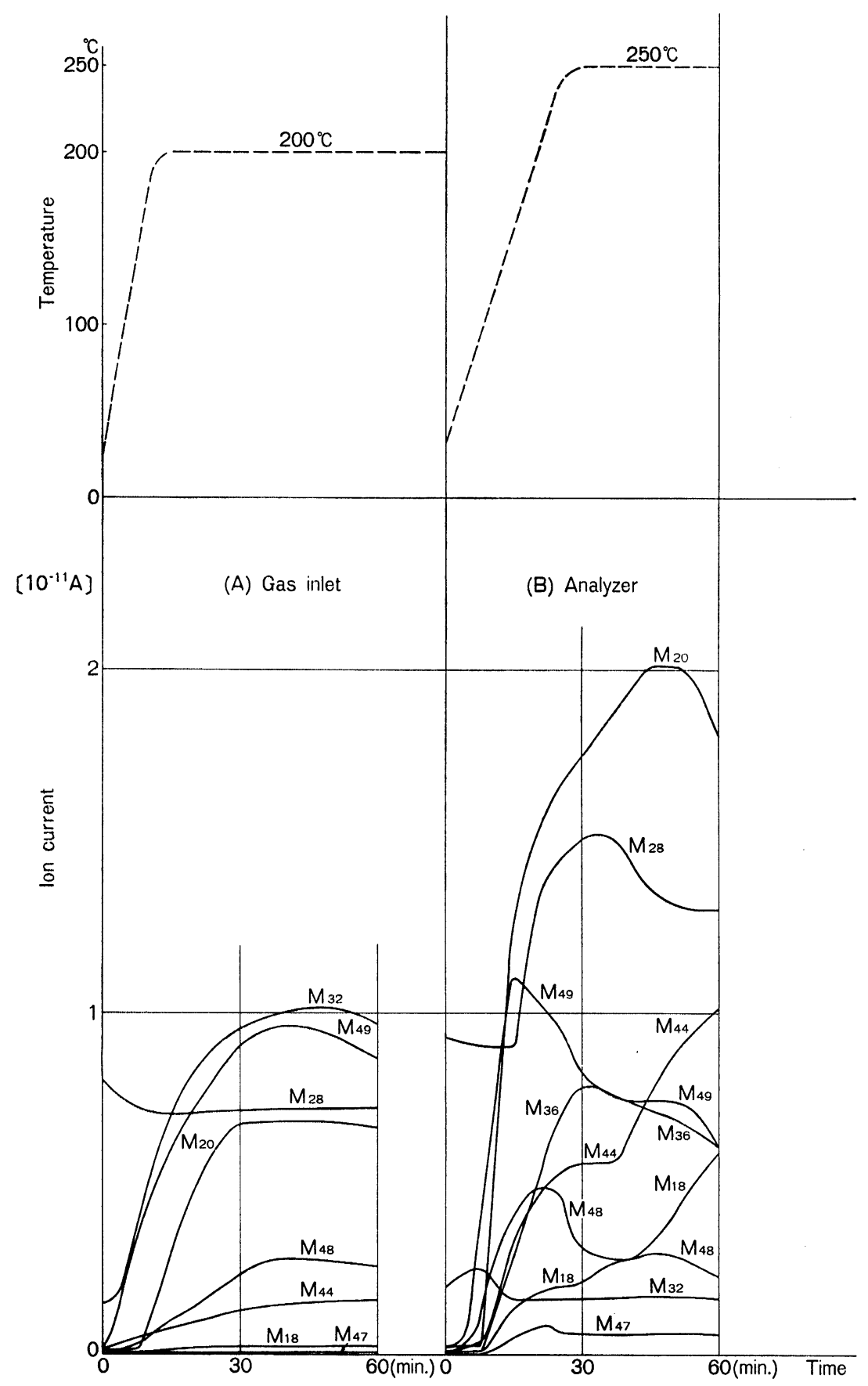

Fig. 6. Relation between time and ion currents of out gases in gas inlet and analyzer on heating. 
星野・里阙

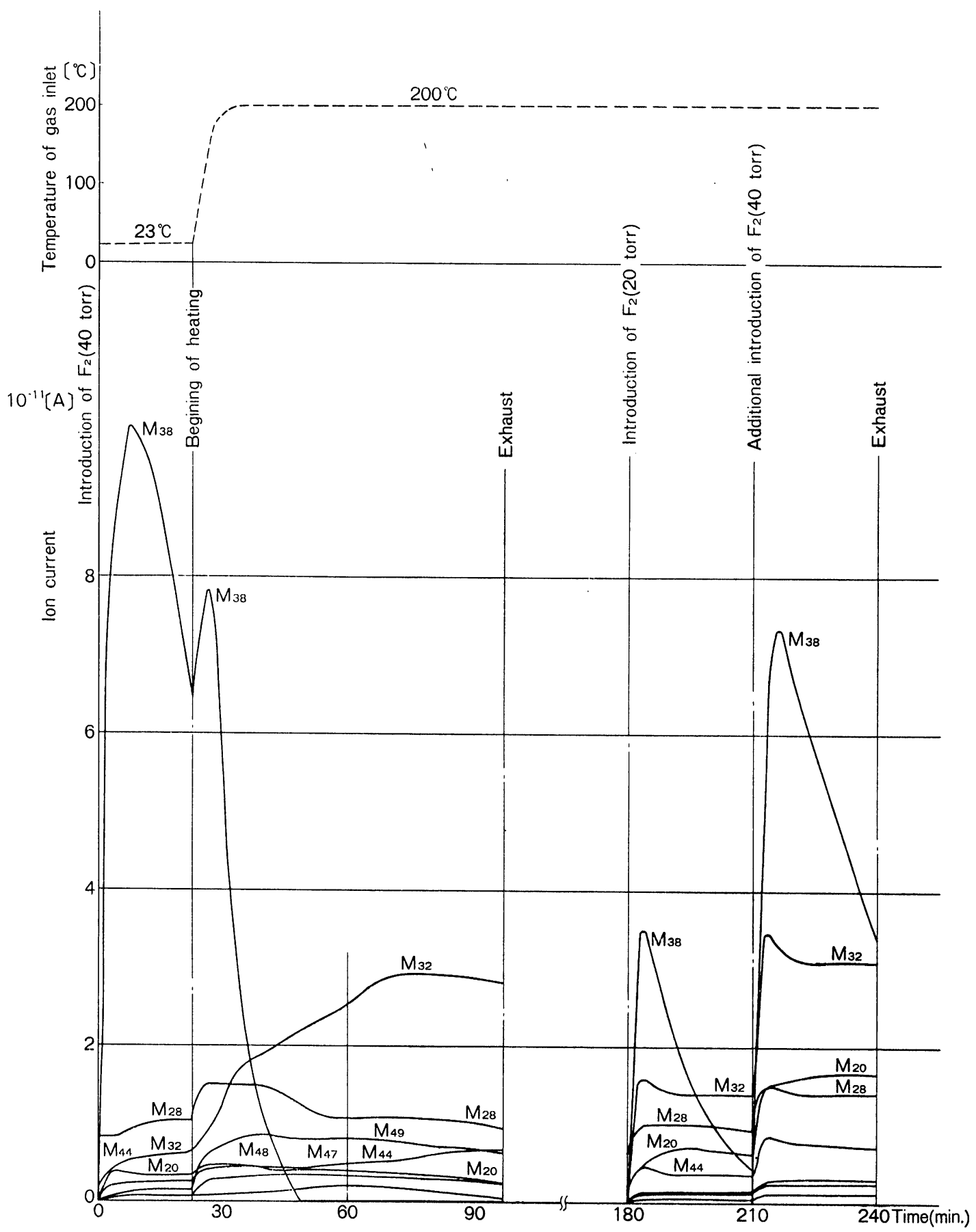

Fig. 7. Relation between time and ion currents of out gases in a gas inlet on heating and by introduction of $F_{2}$ gas.

We can understand that $\mathrm{F}_{2}$ removes $\mathrm{H}_{2} \mathrm{O}$ on the inner surface of the gas inlet and releases $\mathrm{BF}_{3}$ on it. 


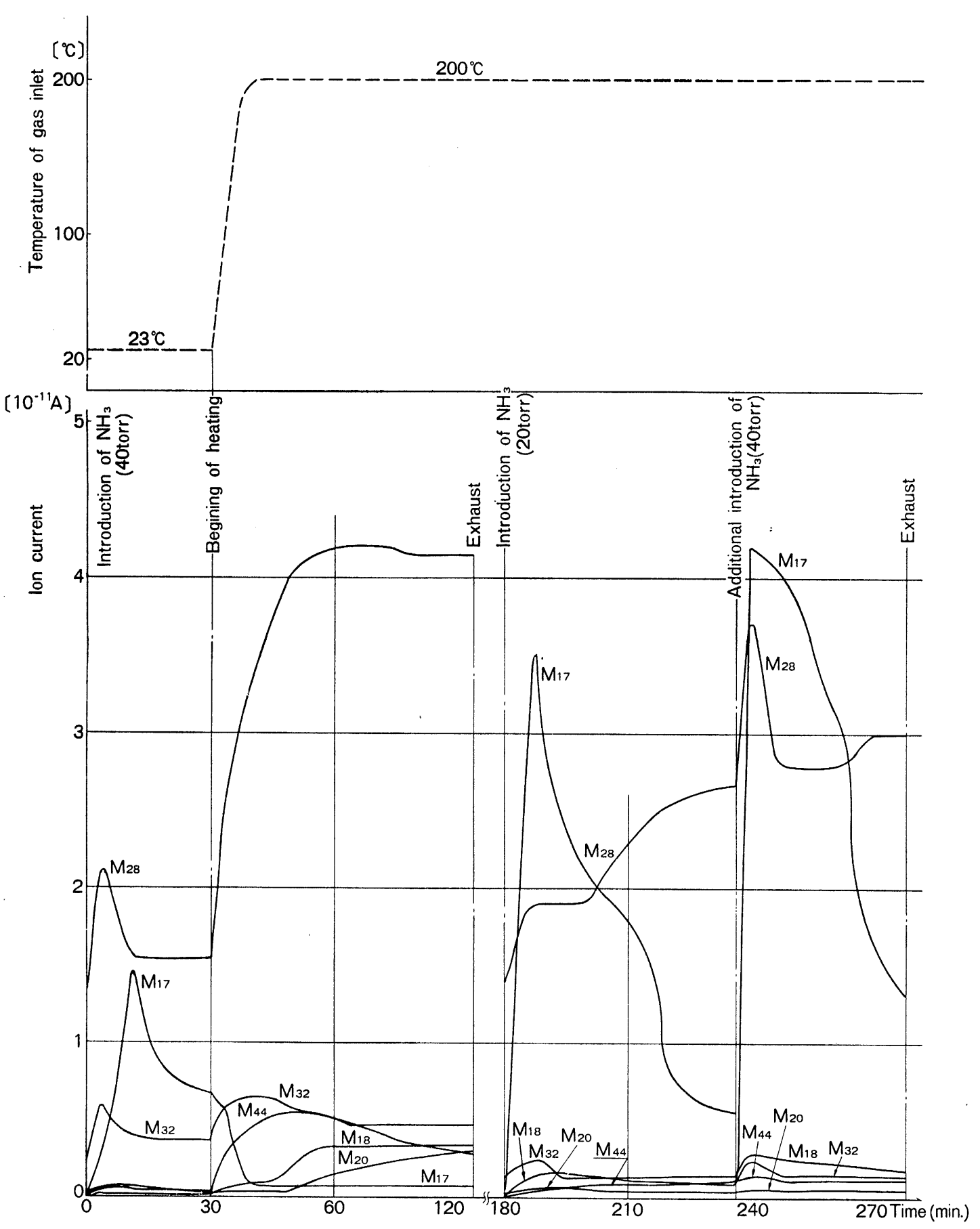

Fig. 8. Relation between time and ion currents of out gases in a gas inlet on heating and by introduction of $\mathrm{NH}_{3}$.

The figure shows the fact that $\mathrm{NH}_{3}$ is decomposed and $\mathrm{N}_{2}$ is produced on heating of the gas inlet, and shows that $\mathrm{NH}_{3}$ does not remove $\mathrm{H}_{2} \mathrm{O}$ and does decompose $\mathrm{BF}_{3}$. 
で增加し，その後急速に減少した。そこで，ガスイン レットを加熱すると，イオン䉓流は一度增加し，急速 に娍少した。室温で $\mathrm{F}_{2}$ をガスインレットに導入する と, $M / e 32$ のイオン䉓流は徐々に增加し，加熱した ら急速に增加した。 $M / e 18\left(\mathrm{H}_{2} \mathrm{O}^{+}\right)$はほとんど現われ なかった。次に，カスインレットを前半の操作に続い て加熱したま〉，充分排気した後， $F_{2}$ (20 Torr，前 半の半分）を導入し，イオン強度が安定してから， $\mathrm{F}_{2}$ (40 Tors) を追加導入したときのイオン強度の変 化を Fig. 7 (右図)に示す。この場合, $M / e 38\left(\mathrm{~F}_{2}{ }^{+}\right)$ のイオン強度は, 前半(左図)と同様, 急速に增加し,
その後急速に減少した。後半(作困)の場合, $M / e 20$ $\left(\mathrm{HF}^{+}\right)$のイオン強度は前半より大きくなり, $M / e 47$ $\left(\mathrm{BFOH}^{+}\right), 48\left({ }^{10} \mathrm{BF}_{2}{ }^{+}\right), 49\left({ }^{11} \mathrm{BF}_{2}{ }^{+}\right)$のオン強度は, 反対に，前半より小さくなった。 $\mathrm{NH}_{3}$ と付着物との関 係を調べた結果を Fig. 8 に示す。文献8)には, $\mathrm{NH}_{3}$ カ スを導入すると, $\mathrm{BF}_{3}$ の付加化合物が分解して追い出 されると述べられている。Fig. 8 の左図は，Fig.7の 場合と同様に室温で $\mathrm{NH}_{3}$ (40 Torr) を導入し，イオ ン全体の強度が安定してから，ガスインレットを加熱 した結果を示す。 $M / e$ 17のイオン強度は, $\mathrm{NH}_{3}$ 尊入 後約15分で最大值 $1.5 \times 10^{-11} \mathrm{~A}$ まで上昇し, その後は

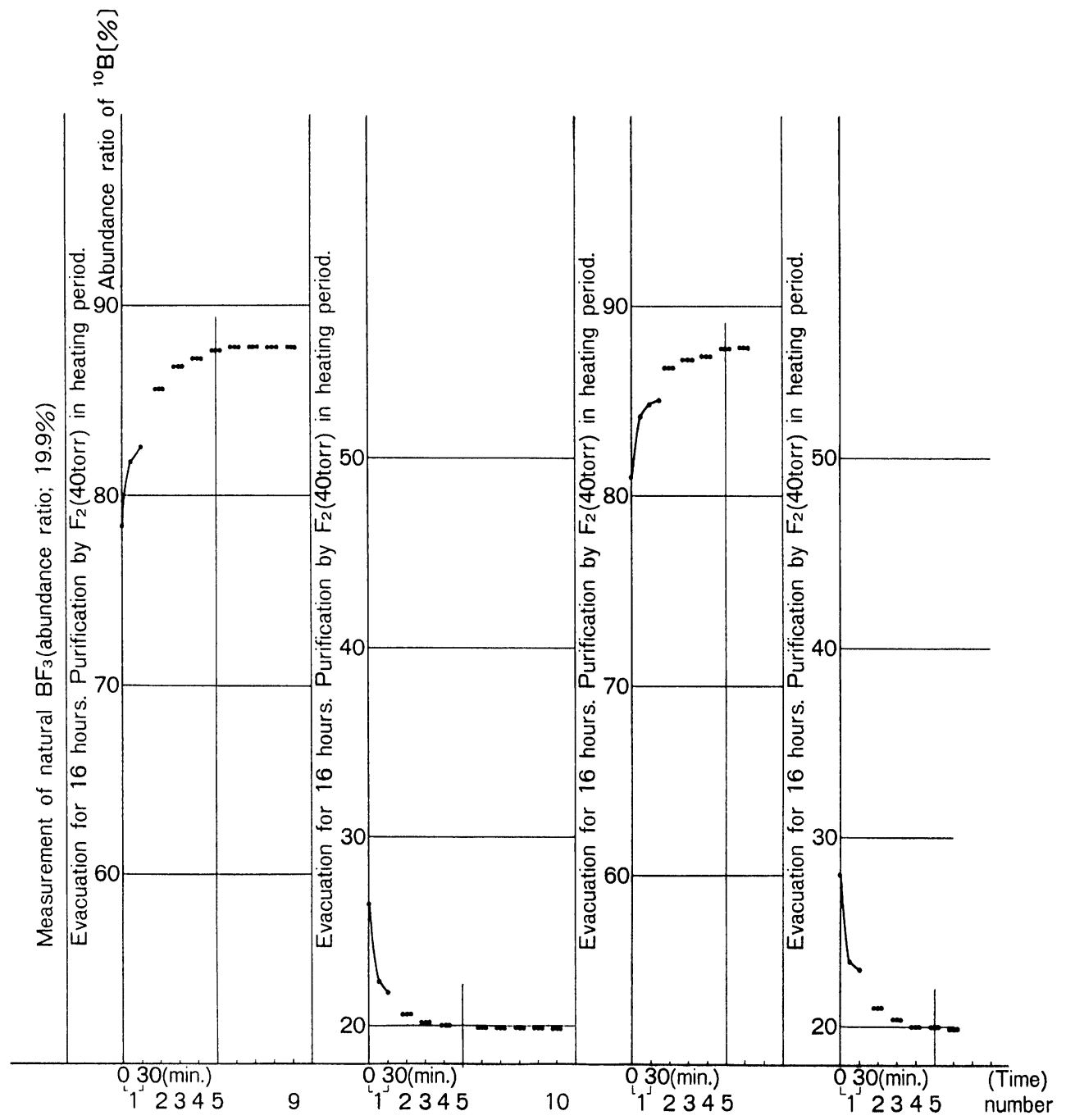

Fig. 9. Memory effect with previous purification by the use of $F_{2}$ gas. 
急速に減少した。M/e $28\left(\mathrm{~N}_{2}{ }^{+}\right)$や $32\left(\mathrm{O}_{2}{ }^{+}\right)$も增加後 最大值を経て隇少し, $M / e 17$ のイオン強度が最大に なる頃から，ほぼ一定になった。30分後にガスインレ ットを加熱すると，M/e 17 のイオン強度はさらに急 速に減少したが, $M / e 28$ のイオン強度は急速に增加 した。これは, 加熱によって $\mathrm{NH}_{3}$ が分解し, $\mathrm{N}_{2}$ が出 来たためと思われる。他に $M / e$ 18，20，32，44など のイオンが現われたが, $\mathrm{BF}_{3}$ からできる $M / e$ 48, 49 のイオンは極めて少なかった。

\section{3. メモリー効果 $\left(\mathrm{F}_{2}\right.$ および $\mathrm{NH}_{3}$ による洗浄の効果 $)$}

4.2.の実験と同様, 装置の污れの度合が問題になる ので, 今回も実験の前に, 濃縮実験の $\mathrm{BF}_{3}$ 試料約 20 検 体を測定した。そのあと，天然の $\mathrm{BF}_{3}$ を測定值が充分 に収斂するまで入れ替えて（9〜12回）測定した。試
料として, ${ }^{10} \mathrm{~B} の$ 濃度が $89.9 \%$ の $\mathrm{BF}_{3}$ ガスと天然の $\mathrm{BF}_{3}$ ガスを用い， $\mathrm{F}_{2}$ または $\mathrm{NH}_{3}$ で洗滌したあと，試料 導入回数と測定值の関係を調べた。ガスインレットの 洗條は, 次のようにした。ガスインレット（試料ビン ショイントを含む）を排気しながら30分間加熱し，温 度が一定になった $\left(200^{\circ} \mathrm{C}\right)$ のち， $\mathrm{F}_{2}$ あるいは $\mathrm{NH}_{3}$ を 導入した。そして15分後に排気してから加熱を止め, ガスインレットの温度が室温 $\left(23 \sim 25^{\circ} \mathrm{C}\right)$ になってか ら，試料を導入して測定を行なった。

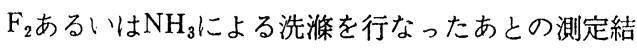
果を Fig. 9 および Fig. 10 に示す。いづれの場合 も，同一試料を何回もガスインレットに導入する操作 を繰り返しながら測定した。各段階の初期の測定值は 時間と共に急速に変わる。時間が記入されていない測 定值は, 試料を導入してから 10 分後に, 1.5 分間隔で

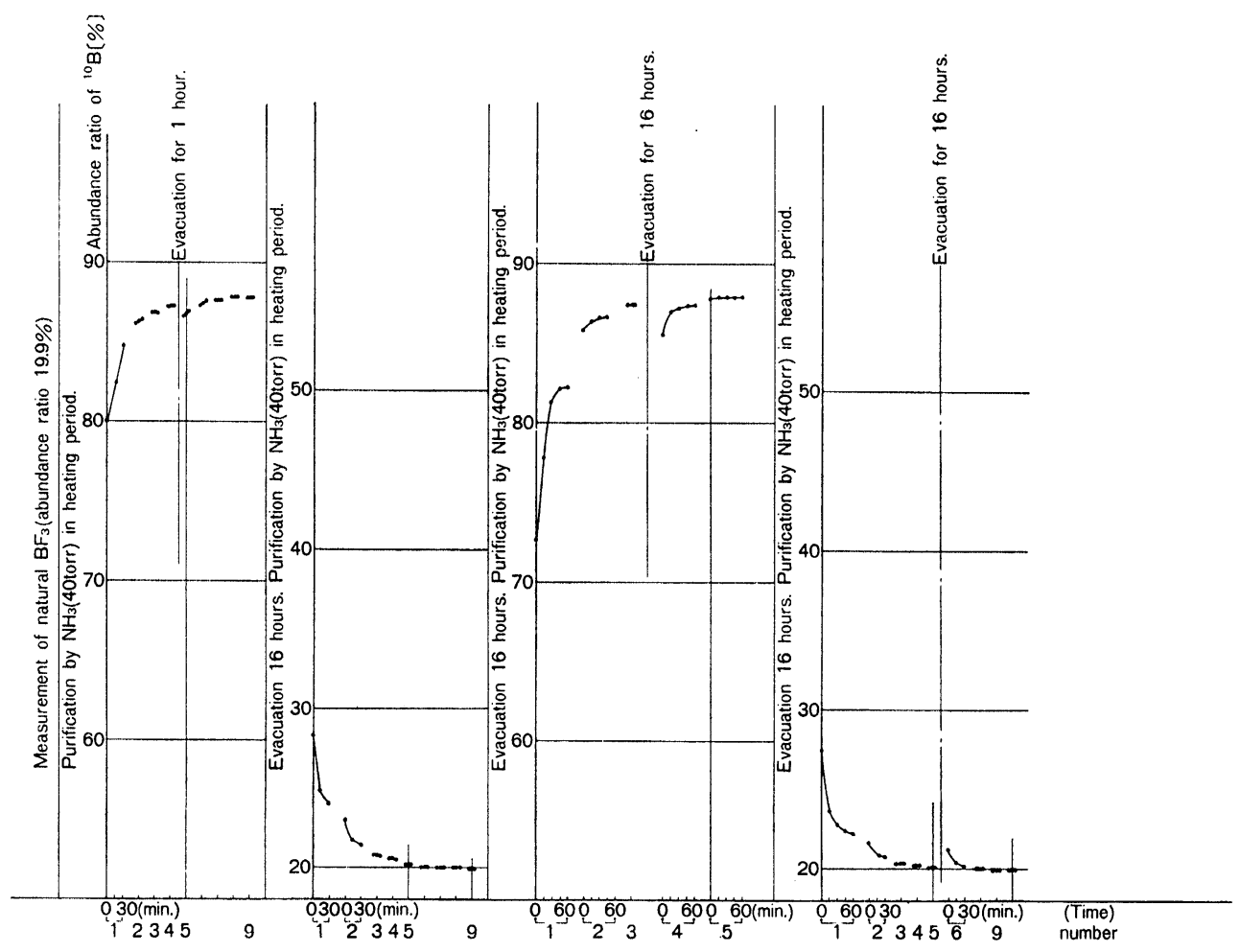

Fig. 10 Memory effect with previous purification by the use of $\mathrm{NH}_{3}$ gas. 
3 回測定した値である。測定終了後の排気の時間は, 特に記入したものを除き，15分間であった。

$\mathrm{F}_{2}$ で洗滌した場合, 各段階の最初の測定では, 試料 導入後 30 分間位は測定值が急速に変った。 2 回目以後 の測定では，試料尊入後10分でほぼ一定值になった。 測定值は，4〜 5 回目の導入で，一定值にほぼ収斂し た。 $\mathrm{NH}_{3}$ で洗滌したときは, 試料導入回数は $\mathrm{F}_{2}$ で洗 滌したとき同様，4〜5回で収㪉值が得られた。この 場合，試料交換のときは，ショイント部は $\mathrm{F}_{2}$ で洗滌し て脱水した。 $\mathrm{NH}_{3}$ で洗滌した場合, 各段階の最初の脟 入では, 測定值が安定するまでの時間は， $\mathrm{F}_{2}$ で洗滌し た場合よりも20〜30分長くかっった。さらに 2 回目に 導入したときも， $\mathrm{F}_{2}$ の場合は試料導入後10分で安定し たが， $\mathrm{NH}_{3}$ の場合は30〜40分を要した。

ガスインレット内部を，加熱しながら $\mathrm{NH}_{3}$ で洗滌し た場合も，測定時間は $\mathrm{F}_{2}$ で処理したときより長くか〉 った。

カススインット内部を， $\mathrm{F}_{2}$ または $\mathrm{NH}_{3}$ で洗湺処理 をしたあと測定を中断して翌日測定した場合（カスイ
ンレットは連続排気しておく), 同じ試料を 再び導入 して測定すると，メモリー効果は導入回数で $1 \sim 2$ 回 少ない上きと同じ程度に增加した。試料を連続的に 反復尊入しないと，消えかけたメモリ一効果が再び現 わ机る。この現象は， $\mathrm{F}_{2}$ や $\mathrm{NH}_{3}$ を使用して洗滌して も，メモリ一効果が完全に消えるわけではないことを 示している。したがって, 測定しようとする試料で器 壁の表面を覆う以外にメモリ一効果を抑える良い方法 はないと思われる。

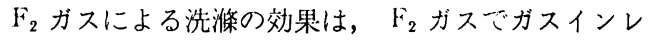
ット全体を 3 回綝返し洗滌した場合でも，1回だけ洗 滌した場合でもメモり一効果に関する限り差はなかっ た。

前処理（加熱， $\mathrm{F}_{2}$ または $\mathrm{NH}_{3}$ による洗滌）を行なわ ないときの測定回数と測定值の関係を Fig. 11 に示し た。この場合も試料突換のときは, ショィイト部は $\mathrm{F}_{2}$ ガスで脱水処理をしてから実験した。Fig. 11に見ら れるように， $\mathrm{F}_{2}$ または $\mathrm{NH}_{3}$ を使用して洗淉したとき に此へ，測定值が収斂するまでに測定回数は少なくと

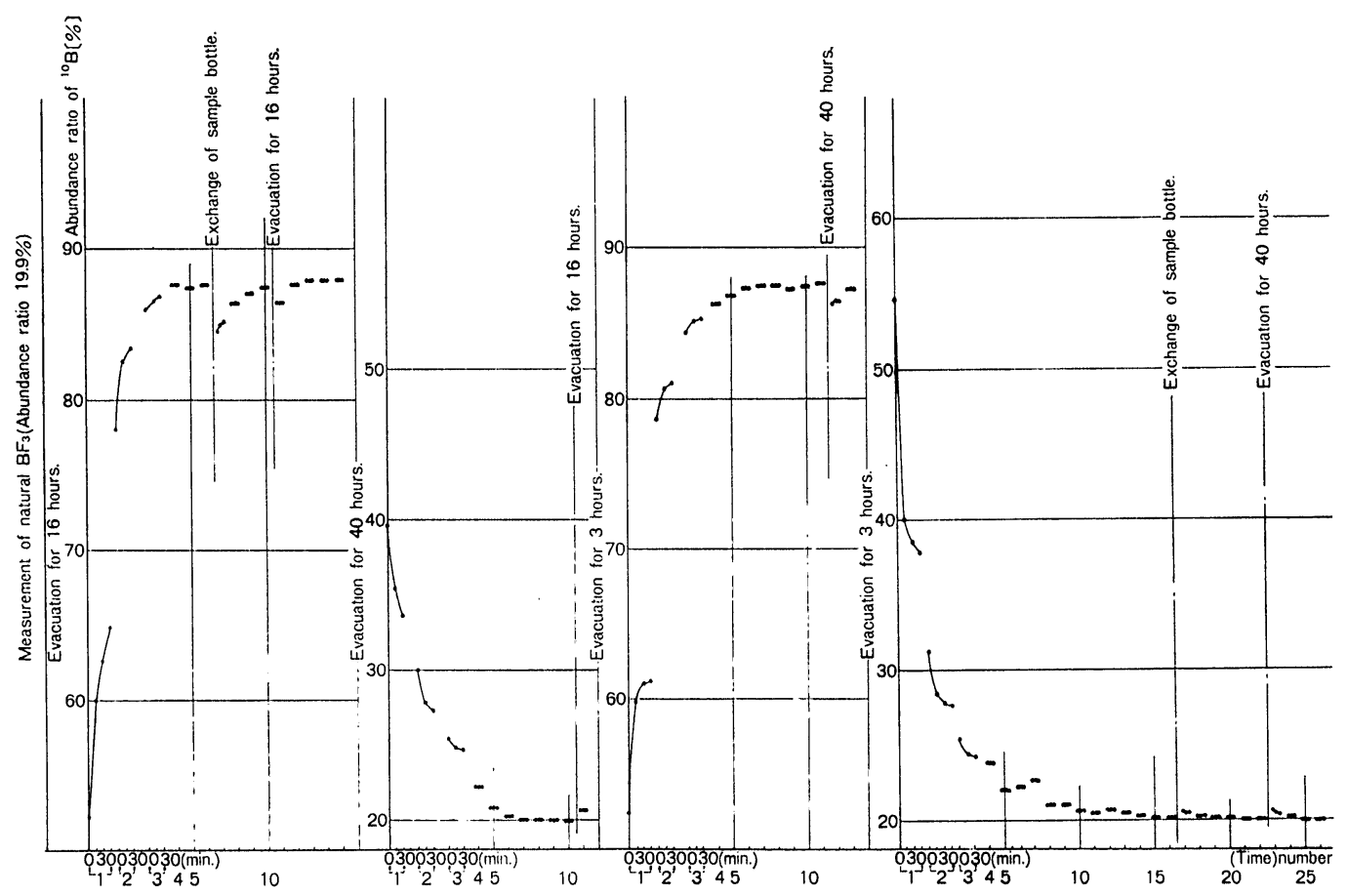

Fig. 11. Memory effect without previous purification. 
も2 倍以上必要であった。測定試料の数が增えるにつ れて, 必要な測定回数は增え,ついには安定した測定 值の収斂值は得られなくなった。これらの結果から明 らかなように, $\mathrm{F}_{2}$ や $\mathrm{NH}_{3}$ で洗策する方法は, メモリ 一効果を少なくすることに有効である。

\section{4. ケミカルポンプの放出ガス}

$\mathrm{F}_{2}$ ガスを回収するため, Fig. 2 に示すようなケミカ ルポンプを使用している。このポンプは何回か $\mathrm{F}_{2}$ ガス
を回収したあと，ポンプ全体を $250^{\circ} \mathrm{C} に$ 加熱して吸収 郕を活性化することにより, 反復使用できる。

Fig. 12 はポンプを加熱したときに放出されるガス をガスインレットに遒入して, マススペクトルを測定 した結果である。ポンプの温度も併記した。図からわ かるように，放出ガスによるイオンは， $M / e 32\left(\mathrm{O}_{2}{ }^{+}\right)$, $44\left(\mathrm{CO}_{2}{ }^{+}\right), 16\left(\mathrm{O}^{+}\right)$で, 大部分は $\mathrm{O}_{2}{ }^{+}$である。 $M / e$ $38\left(\mathrm{~F}_{2}^{+}\right)$は全く現われず， $\mathrm{F}_{2}$ は完全にポンプ内に吸蔵 されていることを意味する。

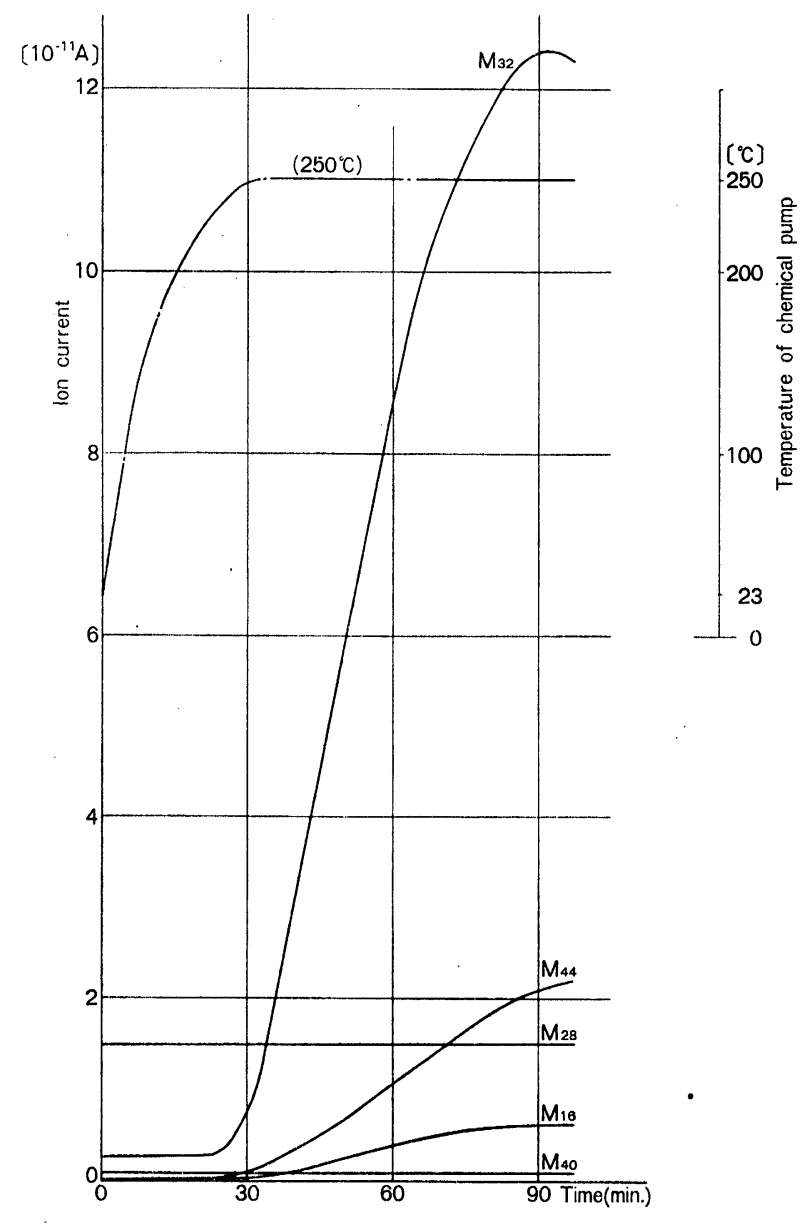

Fig. 12. Relation between time and intensities of ion currents of main peaks of out gases of chemical pump on heating.

The chemical pump does not exhaust $\mathrm{F}_{2}$ gas but $\mathrm{O}_{2}$ gas on baking. 


\section{5. 考察}

第 2 章の (1) 式以下に述べたことと，4.1.で述べた 粘液ができる過程を考虑すると, 試料ビン接続部に付 着する粘液は, 器壁に吸着された大気中の水と試料の $\mathrm{BF}_{3}$ が反応して, 水一 $\mathrm{BF}_{3}$ の化合物ができ, その化合 物に試料ビン接続部の金属が溶けて出来たものと思わ れる。

$\mathrm{NH}_{3}$ ガスをガスインレットに遒入すると, $M / e$ 48, 49 のイオンは全く現われず， $M / e 18$ のイオンは㩆著 に現われ，M/e 20，32，46なとのイオンが現われる。 このことは, $\mathrm{NH}_{3}$ がBF 3 を分解したことを示している。 また, $\mathrm{NH}_{3}$ は水分に対しては，ほとんど影響を与えな いことがわかる。

Fig. 7 からわかることは， $\mathrm{F}_{2}$ を尊入した場合には， $M / e$ 18 $\left(\mathrm{H}_{2} \mathrm{O}^{+}\right)$が全然現われないことと, $M / e$ 48, $49\left(\mathrm{BF}_{3}\right)$ が $\mathrm{F}_{2}$ により器壁から追い出されることであ る。このことは, ガスインレット内の水分除去に $\mathrm{F}_{2}$ が非常に効果があることを示している。また $\mathrm{F}_{2}$ ガスが $\mathrm{BF}_{3}$ を器壁から追い出す効果があることは, $\mathrm{F}_{2}$ がメモ リー効果を減少させる作用があることを意味してい る。

Fig. 9 と Fig. 10 が示す結果から見ると, 測定値の 収斂値が得られるまでの所要時間は, $\mathrm{NH}_{3}$ カススで洗滌 したときは， $\mathrm{F}_{2}$ ガスで洗滌したときの 2 倍以上か る。このことは， $\mathrm{NH}_{3}$ ガスを使用すると， $\mathrm{F}_{2}$ ガスを 使用したときと異なり，水分か残るので，導入した試 料と水分が作用して污れを生じることも一因と思われ る。

ガスインレット内には， $\mathrm{F}_{2}$ で水分を除去しても， $\mathrm{BF}_{3}$ の尊入を繰り返していると，いつの間にか水分が 侵入し, $\mathrm{BF}_{3}$ と水と金属の化合物が多少なりとも生成 する。

4.1・に述べたうに, $\mathrm{BF}_{3}$ と水と金属によって出来 た粘性の化合物は， $F_{2}$ で処理をすると分解して粉末状 になる。したがって,ガスインレット内に存在する水 分によって作られる $\mathrm{BF}_{3}$ の粘性の化合物の被膜は, $\mathrm{F}_{2}$ を導入し温度を上げることにより，粉末状の層にな

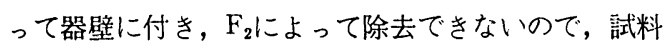
導入を繰り返しているうちに, それが蓄積されていく と思われる。

本質的なメモリー効果は, 金属の酸化物に $\mathrm{BF}_{3}$ が作 用して付加化合物が出来ることが原因である ${ }^{8)}$ と云う 説もある。今回使用したガスインレットは, 高温での
フッ秦処理を数多く繰り返しているので，内面は金属 のフッ化物になっていると思われる。しかし金属の表 面は，初めにフッ化処理をしたのではないので，金属 の酸化物と $\mathrm{BF}_{3}$ からできる付加化合物で覆われている 可能性がある。この場合, ガスインレットの内部は, 金属のフッ化物て覆わ机ているので, $\mathrm{BF}_{3}$ が金属の表 面に吸着してメモリー効果の原因になると云うような 単純なものではないようである。

ガスインレット内にできた粉末状の被膜は，多孔貿 であり，壿入された $\mathrm{BF}_{3}$ に作用して，吸収，化学反 応，放出が行なわれると考えると，メモリ一効果を助 辰する原因になると思われる。この粘性被膜からでき る粉末固体之, 金属の酸化物と $\mathrm{BF}_{3}$ の付加化合物は同 じ構造のものではないかも知れないが, 近い種類のも のであろうと思われる。

Fig. 11 に示寸実験からわかるように, $\mathrm{F}_{2}$ でカススイ ンレットを処理しない上, 前に尊入した試料により作 ら机た粘性化合物の被膜により，メモリ一効果は增大 し, 試料導入を繰り返すうちに,メモリ一効果は一層 增大し, 測定值の信頼度は下がる。

ここで, 付加的メモリ一効果とは, 生成する粘性の 被膜によるメモリ一効果を指しているが，これを除く ための洗滌処理をすると，その被膜は本質的メモリ一 効果を助辰する被膜に変化すると思われる。

\section{6. 結 論}

金属製の $\mathrm{BF}_{3}$ 用ガスインレットにつきまとうメモリ 一効果は，本質的なものと，付加的なものに分けられ る。本質的なものとは, ガスインレット，イオン源な との器壁の金属と $\mathrm{BF}_{3}$ から出来る固体の化合物による ものである。

付加的メモリ一効果とは一- $\mathrm{BF}_{3}$ に拀いて特に大き いと思われるが一一水分と $\mathrm{BF}_{3}$ の化合物が, 金属と反 応して作る粘液によって引き抗されるものである。 この粘液はガスインレット全体で発生する可能性があ るが, 特にショィント部に出来易く, インレットのバ ルブを操作するたびに, インレット全体に拡がり, 器 壁上に被膜を形成する。この被膜が付加的メモリ一効 果を引き抗こす。付加的メモリ一効果は，ガスインレ ットを長く使用していると，本質的メモリ一効果より 顕著になってくる。

付加的メモリ一効果を防ぐには, ビン中に水分が存 在しないように工夫することと, 試料ビンショョイント 
の空気が入る部分の水分を除去してから， $\mathrm{BF}_{3}$ を導入 することが必要である。ジョイント部の水分を除くた めには， $\mathrm{F}_{2}$ ガスを導入して，加熱したのち排気すれ ばよい。質量分析計を設置した部屋でフツ素ガスを取 り扱う場合，マグネシウムの細片とモレキュラシーブ の二層からなるケミカルポンプを用いて排気すればフ ツ素ガスは完全にケミカルポンプに捕えられる。ポン プ活性化のため加熱しても，フッ素ガスは完全に吸蔵 されて放出されない。

測定前の処理としてガスインレット全体に $\mathrm{F}_{2}$ ガスを 入れて加熱すると, 水分に基づく污染が減少し，メモ リー効果が改善される。 $\mathrm{F}_{2}$ ガスの処理によって，本貿 的メモリ一効果が減少したのか否かは明らかでない。 $\mathrm{NH}_{3}$ ガスを用いて前処理をした場 合，その効力は $\mathrm{F}_{2}$ の場合に比べて劣る。

おわりに，本装置を製作するときお世話になった当 研究室の皆様ならびに, 特に文献の調査や化学分析に 協力下さった大山俊之研究員, ${ }^{10} \mathrm{~B}$ 濃度 $90 \%$ の $\mathrm{BF}_{3}$ 試 料を提供して下さった三菱金属中央研究所の富沢憲治 氏に対し，心から感謝の意を表します。
文献

1）星野紀一，理研報告，35（昭. 34）99.

2）星野紀一，理研報告，52（昭. 51） 93.

3) C. A. Wamser, J. of Am. Chem. Soc., 73, 409 (1951).

4) P. Diehl, Helv, Phys. Acta., 31, 685 (1958).

5) J. S. Mac Grath, G. G. Stack and P. A. Mecusher, J. of Am. Chem. Soc., 66, 1263 (1944).

6) N. N. Greenwood and R. L. Martin, J. of Chem. Soc., 1915 (1951).

7) P. G. Bently, J. of Sci. Instr., 37, 323 (1960).

8) G. M. Murphy, "Seperation of the Boron Isotopes", U.S. Atomic Energy Commission, 1952.

\section{Keywords}

Ion source for $\mathrm{BF}_{3}$

Gas inlet for $\mathrm{BF}_{3}$

Chemical pump for $\mathrm{F}_{2}$ gas

Dehydrate technique of gas inlet

Reaction between $\mathrm{BF}_{3}$ and $\mathrm{H}_{2} \mathrm{O}$ 